\title{
GATA2 mutations in patients with non-tuberculous mycobacterial or fungal infections with unknown immunodeficiency in Brazil
}

Daniela Palheiro Mendes de Almeida ( $\boldsymbol{\nabla}$ daniela.almeida@ini.fiocruz.br)

Fundação Oswaldo Cruz https://orcid.org/0000-0002-1936-4774

Francianne G. Andrade

Instituto Nacional de Cancer

Filipe V. dos Santos-Bueno

Instituto Nacional de Cancer

Dayvison F. Saraiva Freitas

Fundacao Oswaldo Cruz

Rosely M. Zancopé-Oliveira

Fundacao Oswaldo Cruz

Maria S. Pombo-de-Oliveira

Instituto Nacional de Cancer

Research article

Keywords: GATA2 gene mutation, MonoMAC syndrome, myelodysplastic syndrome, primary immunodeficiency, non-tuberculous mycobacterial infection, invasive fungal

Posted Date: April 15th, 2020

DOI: https://doi.org/10.21203/rs.3.rs-19675/v1

License: (c) (1) This work is licensed under a Creative Commons Attribution 4.0 International License. Read Full License 


\section{Abstract}

Background Non-tuberculous mycobacteria (NTM) and invasive fungal infections (IFI) may be considered opportunistic infections in immunocompromised patients with GATA2 haplodeficiency. Sporadic or familial GATA2 mutations are associated with infection susceptibility, autoimmunity, and myelodysplastic syndrome (MDS) and acute myeloid leukemia (AML). This work aimed to investigate GATA2 status in patients with NTM and/or IFI with unknown causes for immunodeficiency .

Methods A series of incident patients with NTM and/or IFI from the Division of Hematology of the Institute of Infectious DiseasesFIOCRUZ at Rio de Janeiro, Brazil, from 2015 to 2018 were subject to GATA2 genotyping. Patients with HIV positivity or other immunodeficiencies were excluded.

Results. Twenty-two patients and 9 of their relatives were enrolled. Seventeen patients had IFI, 4 NTM, and one patient present both infections. In 6 patients, the occurrence of malignant disease was found along with this infection, with MDS/AML $(n=3)$ being the most frequent. The pathogenic T354M mutation was found in 4.5\% (1/22) of patients and asymptomatic offspring (2/9). We also found the GATA2 polymorphisms rs 2335052 and rs 369850507 in $18.2 \%$ and $4.5 \%$, respectively, and the rs 11708606 intronic polymorphisms in $27.3 \%$ of cases.

Conclusions GATA2 mutations are substantial findings in patients with NTM and/or IFI without known immunosuppression. As it can indicate a primary immunodeficiency and lead to cancers - particularly MDS and AML- the presentation with NTM or IFI should trigger GATA2 mutation testing. The carriers should receive genetic counseling, subsequent infection prevention measures, and surveillance for hematologic malignancies.

\section{Introduction}

Non-tuberculous mycobacteria (NTM) are infections caused by largely non-pathogenic organisms and, the immune host defects that may underly it were recently reviewed (1). Advances in imaging, microbiological, and molecular techniques have contributed to the recognition of these infections leading to an apparent increased incidence rate over time (2). Morbidity caused by NTM is clinically manifested by lymphadenitis, skin, and pulmonary diseases. The outcome of NTM infection depends upon a complex interaction between exposure, duration of host exposure, immune status, and genetic background (3). Overall, patients with immunodeficiencies, whether primary or acquired, are at risk of developing NTM or invasive fungal infections (IFI) (4). Nowadays, the recognition of the underlying genetic background for NTM and/or IFI understanding is essential for therapy and prognostic assessment. For instance, mutations in interleukin 12-interferon y pathway genes (INGR1/2, IL 12b, STAT1) are often associated with the onset of opportunistic infections in early childhood, while GATA2 mutations give rise to disseminated infection in late childhood or adulthood (1).

The GATA2 gene is located on chromosome 3q21 region, coding a 3,730 kb GATA2 protein. GATA2 has six exons and two zinc-finger domains, and it acts as a transcriptor factor in several tissues (5). GATA2 is mostly expressed in hematopoietic progenitor, myeloid, and mast cells (6). GATA2 haplodeficiency in sporadic and familial mutations was found associated with MonoMAC syndrome that clinically presents decreases of monocytes, T, B and NK cell, viral, and bacterial infections autoimmunity and pulmonary alveolar proteinosis. Additionally, GATA2 haplodeficiency is associated with lymphedema, warts, and deafness, condition named Emberger syndrome. Both MonoMAC and Emberger syndromes predispose patients to myelodysplastic syndrome (MDS) and acute myeloid leukemia (AML) (5). Because of the importance of identifying the underlying causes of overt immunodeficiency in patients with NTM and or IFI infections, this study aimed to identify GATA2 variants among such individuals and to establish the association with clinicalphenotypic features. The heterogeneity of GATA2 aberrations might be reflected in the broad range of clinical features and deserve a distinctive approach to a multidisciplinary team.

\section{Methods}

\section{Subjects}

A series of incident patients with pulmonary or disseminated NTM and/or IFI (older than 12 years old) were investigated between 2015 to 2018. Demographic, clinical, and laboratory features were extracted from the patients' charters and follow-up. A complete blood count was performed, from which the monocyte count was obtained, when the patients entered the study (Supplemental Table 1). Human immunodeficiency virus (HIV) serology was tested in all patients. To confirm the infectious diagnosis, direct microscopic examination, histopathological, and culture analysis was performed. Bone marrow puncture for a myelogram, immunophenotyping, cytogenetics, and 
histopathological examination was performed in patients who presented sustained unexplained cytopenias or organomegaly (Supplemental Table 2).

The exclusion criteria were patients with a prior diagnosis of other primary or secondary immunodeficiency such as acquired immunodeficiency syndrome (AIDS)/HIV infection, well established autoimmune diseases such as rheumatoid arthritis, solid organ transplantation, cystic fibrosis, and immunosuppressive or chemotherapeutic treatments.

\section{GATA2 genotyping}

Genomic DNA was extracted from peripheral blood samples using the commercial QIAamp DNA Blood Mini kit (Qiagen, CA, USA) according to the manufacturer's instructions. Sanger sequencing was performed throughout the five coding exons $(2,3,4,5$, and 6$)$ and intron 4 of the GATA2 using the oligo primers and reagents protocols according to Wang et al (7). GATA2 mutation found in the proband was investigated in the relatives. All PCR products were sequenced using the ABI3500xl automatic gene analyzer (Applied Biosystems, CA, USA). Sequences were analyzed in the Mutation Surveyer® program (Softgenetics, PA, USA). Genetic variants found in the GATA2 gene were compared to the reference databases available online at https://cancer.sanger.ac.uk/cosmic, https://www.ncbi.nlm.nih.gov/clinvar, and www.ensemble.org, to evaluate the population frequency and gene variant clinical association.

\section{Statistical Analysis}

We used a convenience patients sampling recruited during outpatient and inpatient hematology consults. The frequency analysis was calculated through IBM® SPSS Statistics version 22.0.

\section{Results}

Twenty-seven patients fulfilled the inclusion criteria in the study, but 5 patients declined the invitation to participate in the GATA2 genotyping investigation. Thirty-one samples from 22 patients and 9 healthy relatives from a single family were genotyped (shown in Fig. 1). There was a predominance of males and white patients (63.6\%; $59.1 \%$, respectively). The median age was 45.5 years old (range 19-75 years). The most frequent opportunistic infections were IFI (77.3\%) followed by NTM (18.2\%), and in one patient, both diseases concomitantly were found (4.5\%). Fungal and mycobacterial infections found were: histoplasmosis, sporotrichosis, paracoccidiomycosis, aspergillosis, and candidosis (IFI) in 17 patients, and M. Kansassi, M.abscessus, M.fortuitum and M.intracellulare (NTM) in 5 patients. Viral infections didn't fit inclusion criteria, but we observed herpes simplex virus and varicella-zoster virus in two ascertained patients, as shown in Fig. 2.

The demography, infectious agent, diseases, and genotyping of GATA2 are shown in Table 1. Single nucleotide variants were found in 10 out 22 patients (45.4\%), with polymorphism in exon 3 and 5 being the most frequent genetic alteration. Four genetic variants were identified. The minor allele frequency of each single nucleotide polymorphism (SNP) varyied from $4.0,12.3$, and $23 \%$ rate in the general population and are shown in Table 1. Four patients presented the variant c.490 G > A; p. 164 A > T (rs2335052) in exon 3. We also identified the SNPs g.11223 C > T (rs11708606) in 6 patients (27,3\%) and g.11199 G > A (rs369850507) in 1 patient (4.5\%). Only one patient presented the pathogenic loss-of-function missense mutation c.1061 C> T; p. T354M. The same mutation was identified in both asymptomatic offspring, and his clinical presentation and pedigree were described elsewhere (9). 
Table 1

Summary of main clinical findings and GATA2 aberrations, Brazil 2015-2018

\begin{tabular}{|c|c|c|c|c|c|c|c|c|}
\hline Patient & $\begin{array}{l}\text { Age/Sex/ } \\
\text { Ethnicity }\end{array}$ & $\begin{array}{l}\text { Infectious } \\
\text { diagnosis }\end{array}$ & $\begin{array}{l}\text { Neoplastic } \\
\text { diagnosis }\end{array}$ & $\begin{array}{l}\text { Rheumatological } \\
\text { manifestation }\end{array}$ & $\begin{array}{l}\text { GATA2 } \\
\text { variant }\end{array}$ & $\begin{array}{l}\text { Type of } \\
\text { variant }\end{array}$ & $\begin{array}{l}\text { MAF } \\
(\%)\end{array}$ & $\begin{array}{l}\text { Follow- } \\
\text { up }\end{array}$ \\
\hline 1. & 75/M/W & M. kansasii & MDS/ AML & No & $\begin{array}{l}\text { rs2335052 in } \\
\text { exon } 3\end{array}$ & Polymorphism & 23 & Dead \\
\hline 2. & $50 / \mathrm{M} / \mathrm{W}$ & M. kansasii & MDS & $\begin{array}{l}\text { Arthritis, } \\
\text { vasculitis, } \\
\text { erythema } \\
\text { nodosum }\end{array}$ & $\begin{array}{l}\text { T354M in } \\
\text { exon } 5\end{array}$ & $\begin{array}{l}\text { Pathogenic } \\
\text { Mutation }\end{array}$ & - & Dead \\
\hline 3. & 19/M/W & PCM & - & No & $\begin{array}{l}\text { rs369850507 } \\
\text { and } \\
\text { rs11708606, } \\
\text { both in exon } \\
5\end{array}$ & Polymorphism & $\begin{array}{l}04 \\
\text { and } \\
12.3\end{array}$ & Dead \\
\hline 4. & $\begin{array}{l}55 / F / N- \\
W\end{array}$ & M. fortuitum & Melanoma $^{1}$ & No & $\begin{array}{l}\text { rs } 2335052 \\
\text { in exon } 3 \\
\text { and } \\
\text { rs } 11708606 \\
\text { in exon } 5\end{array}$ & Polymorphism & $\begin{array}{l}23 \\
\text { and } \\
12.3\end{array}$ & Dead \\
\hline 5. & $57 / \mathrm{M} / \mathrm{W}$ & Histoplasmosis & $\mathrm{NHL}$ & No & - & - & - & Alive \\
\hline 6. & $\begin{array}{l}52 / \mathrm{F} / \mathrm{N}- \\
\mathrm{W}\end{array}$ & Sporotrichosis & - & $\begin{array}{l}\text { Erythema } \\
\text { nodosum }\end{array}$ & - & - & - & Alive \\
\hline 7. & $\begin{array}{l}37 / \mathrm{M} / \mathrm{N}- \\
\mathrm{W}\end{array}$ & $\begin{array}{l}\text { Histoplasmosis } \\
\text { and HSV }\end{array}$ & - & No & $\begin{array}{l}\text { rs } 11708606 \\
\text { in exon } 5\end{array}$ & Polymorphism & 12.3 & Alive \\
\hline 8. & $\begin{array}{l}42 / \mathrm{F} / \mathrm{N}- \\
\mathrm{W}\end{array}$ & Histoplasmosis & Ovary & No & - & - & - & Alive \\
\hline 9. & $\begin{array}{l}25 / \mathrm{M} / \mathrm{N}- \\
\mathrm{W}\end{array}$ & PCM & - & No & $\begin{array}{l}\text { rs2335052 in } \\
\text { exon } 3\end{array}$ & Polymorphism & 23 & Dead \\
\hline 10. & 40/F/W & $\begin{array}{l}\text { M. } \\
\text { intracellulare }\end{array}$ & - & No & - & - & - & Dead \\
\hline 11. & $\begin{array}{l}74 / \mathrm{F} / \mathrm{N}- \\
\mathrm{w}\end{array}$ & Sporotrichosis & - & No & - & - & - & Alive \\
\hline 12. & $58 / \mathrm{M} / \mathrm{W}$ & $\begin{array}{l}\text { Histoplasmosis } \\
\text { and Candidosis }\end{array}$ & - & Arthralgia & $\begin{array}{l}\text { rs } 11708606 \\
\text { in exon } 5\end{array}$ & Polymorphism & 12.3 & Alive \\
\hline 13. & $\begin{array}{l}49 / \mathrm{M} / \mathrm{N}- \\
\mathrm{w}\end{array}$ & Sporotrichosis & $\begin{array}{l}\text { MDS and } \\
\text { Melanoma }^{2}\end{array}$ & No & - & - & - & Alive \\
\hline 14. & $\begin{array}{l}36 / \mathrm{F} / \mathrm{N}- \\
\mathrm{W}\end{array}$ & Sporotrichosis & - & Arthralgia & $\begin{array}{l}\text { rs } 11708606 \\
\text { in exon } 5\end{array}$ & Polymorphism & 12.3 & Alive \\
\hline 15. & $55 / \mathrm{M} / \mathrm{W}$ & $\begin{array}{l}\text { Histoplasmosis } \\
\text { and HSV }\end{array}$ & - & No & - & - & - & Alive \\
\hline 16. & $58 / \mathrm{M} / \mathrm{W}$ & Histoplasmosis & - & No & - & - & - & Alive \\
\hline 17. & $59 / \mathrm{M} / \mathrm{W}$ & $\begin{array}{l}\text { Aspergillosis } \\
\text { and } M \text {. } \\
\text { abscessus }\end{array}$ & - & Arthralgia & $\begin{array}{l}\text { rs } 11708606 \\
\text { in exon } 5\end{array}$ & Polymorphism & 12.3 & Alive \\
\hline 18. & 24/M/W & Histoplasmosis & - & No & - & - & - & Alive \\
\hline 19. & $\begin{array}{l}29 / \mathrm{M} / \mathrm{N}- \\
\mathrm{W}\end{array}$ & PCM & - & No & - & - & - & Alive \\
\hline
\end{tabular}

M- Male; F- Female; W- White; N-w- Non-white; FH - Familial history; PCM - Paracoccidioidomycosis; HSV- Herpes simplex virus; VZVVaricella-zoster virus; NTM- Nontuberculous mycobacteria; MDS- Myelodysplastic syndrome; AML- Acute myeloid leukemia; NHLNon-Hodgkin Lymphoma of skin; ${ }^{1}$ : Intestinal Melanoma; ${ }^{2}$ : Palmar Melanoma; MAF - Minor allele frequency in the population. 


\begin{tabular}{|c|c|c|c|c|c|c|c|c|}
\hline Patient & $\begin{array}{l}\text { Age/Sex/ } \\
\text { Ethnicity }\end{array}$ & $\begin{array}{l}\text { Infectious } \\
\text { diagnosis }\end{array}$ & $\begin{array}{l}\text { Neoplastic } \\
\text { diagnosis }\end{array}$ & $\begin{array}{l}\text { Rheumatological } \\
\text { manifestation }\end{array}$ & $\begin{array}{l}\text { GATA2 } \\
\text { variant }\end{array}$ & $\begin{array}{l}\text { Type of } \\
\text { variant }\end{array}$ & $\begin{array}{l}\text { MAF } \\
(\%)\end{array}$ & $\begin{array}{l}\text { Follow- } \\
\text { up }\end{array}$ \\
\hline 20. & $30 / F / W$ & $\begin{array}{l}\text { Histoplasmosis } \\
\text { and VZV }\end{array}$ & - & Arthralgia & - & - & - & Alive \\
\hline 21. & $30 / \mathrm{M} / \mathrm{W}$ & Histoplasmosis & - & No & $\begin{array}{l}\text { rs } 2335052 \text { in } \\
\text { exon } 3\end{array}$ & Polymorphism & 23 & Alive \\
\hline 22. & 39/F/W & Histoplasmosis & - & No & - & - & - & Alive \\
\hline
\end{tabular}

Six patients developed neoplasms in addition to the infectious condition and had not received any immunosuppressor treatment before the study: three with MDS, two with melanoma (one patient presented MDS and melanoma simultaneously), one with diffuse B-cell nonHodgkin lymphoma and one patient with ovarian neoplasm (Shown in Table 1). Six patients presented with rheumatologic symptoms. The mortality observed was $27.3 \%$ ( 6 patients).

\section{Discussion}

Since the first description of GATA2 haploinsufficiency as associated with primary immunodeficiency in 2011, there have been 624 pathogenic mutations described so far (https://cancer.sanger.ac.uk/cosmic). Herein, we present the prevalence of GATA2 genetic polymorphisms in Brazilian patients with NTM and/or IFI of unknown origin. Overall, $45.5 \%$ of the patients had one SNP alteration in GATA2, although a known pathogenic mutation was found in $4.5 \%$ of the patients with NTM and/or IFI infections. According to the Cosmic database, the majority of GATA2 mutations are missense $(74.4 \%)$, and the most frequent nucleotide changes are $\mathrm{G}>\mathrm{A}(30.3 \%)$ and $\mathrm{C}>\mathrm{T}(25.5 \%)$.

T354M is one of the most prevalent mutations associated with MonoMAC syndrome and is located at the second zinc finger domain (8). We identified this mutation in one patient and his two healthy sons. This identification was essential to drive his treatment as he was submitted received a hematopoietic stem cell transplant with his GATA2-wild type brother as his donor; in addition his his offspringwere able to receive genetic counseling for prevention and early complication recognition. Although it was not a pathogenic variant and does not affect the zinc finger regions, the rs2335052 is located in a coding and regulatory region and may contribute to the GATA2 protein expression. This polymorphism has been previously associated with worse prognosis in a colon cancer study (12). It is unknown if the presence of this SNP may have contributed to the poor outcome of the cases. The polymorphisms rs 11708606 and rs369850507 observed in our patients do not lead to amino acid substitution, as they are located in a non-coding region and are not associated with clinical diseases.

With this study, we reinforce the need for multidisciplinary care of NTM and/or IFI infected patients with unknown causes for immunodeficiency, considering a hidden germline GATA2 haplodeficiency. The identification of a pathogenic variant in one patient was not only useful for himself but also for his family. The identification of other non-pathogenic variants may be related to the clinical prognosis and can be better explored in future clinical association studies. Finally, we had limitations in this small and descriptive work; in particular we couldn't rule out other causes of primary immunodeficiencies because we did not investigate such conditions.

\section{Conclusions}

GATA2 mutations are substantial findings in patients with NTM and/or IFI without known immunosuppression. As it can indicate a primary immunodeficiency and lead to cancers - particularly MDS and AML- the presentation with NTM or IFI should trigger GATA2 mutation testing. The carriers should receive genetic counseling, subsequent infection prevention measures, and surveillance for hematologic malignancies. Further studies on the prevalence, expression, and clinical significance of variants in the GATA2 gene are necessary to know this condition in all its complexity and to be able to indicate the best and safer treatment.

\section{Abbreviations}


NTM: non-tuberculous mycobacteria; IFI: invasive fungal infections; MDS: myelodysplastic syndrome; AML: acute myeloid leukemia; HIV: Human immunodeficiency virus; AIDS: acquired immunodeficiency syndrome; SNP: single nucleotide polymorphism.

\section{Declarations}

\section{Ethics approval and consent to participate}

Patients were treated following the Declaration of Helsinki. Written informed consent was obtained from the individuals to participate in this research. Parents, offsprings, siblings, and nephews (first and second-degree relatives) of patients with GATA2 mutations identified were also subject to this study. Ethics and Research Committee of Evandro Chagas National Institute of Infectious Diseases for Clinical Research approved the project (\#CAAE 64574417.0.0000.5262).

\section{Consent for publication}

Written informed consent for publication of the clinical information and molecular data were obtained. All this information is available for the journal.

\section{Availability of data and materials}

The clinical documentation is available to the corresponding author on reasonable request.

\section{Competing interests}

The authors declare no competing financial interests.

\section{Funding}

This study was financed in part by the Coordenação de Aperfeiçoamento de Pessoal de Nível Superior - Brasil (CAPES) - Finance Code 001; M.S.P.O. and R.M.Z.O. are supported by Conselho Nacional de Desenvolvimento Científico e Tecnológico- CNPq [\#302423/2010-9 and \#302796/2017-7], and by Fundação de Amparo à Pesquisa do estado do Rio de Janeiro - FAPERJ [E-26/203.076/2016].

\section{Author's contributions}

D.P.M.A. designed the study, collected, and analyzed clinical data. DPMA and MSPO wroten the manuscript; D.P.M.A., F.G.A., and F.V.S.B. performed the genetic tests; D.F.S.F. attended patients and revised the article; M.S.P.O. and R.M.Z.O. design, provided funding, supervised the study, all authors have seen and approved the manuscript and its submission.

\section{Acknowledgments}

The authors thank the patients and relatives who made samples available, provided written informed consent, and helped with information. We also thank the many physicians who provided data and clinical details, particularly Dr. Valeria Rolla, head of Clinical Research Laboratory on Mycobacteriosis of INI-FIOCRUZ. We thank Alexandre Vizzoni for the laboratory and databank support and Prof. Logan Spector for critical revision of the manuscript. The authors are also grateful to the INI-FIOCRUZ Flow Cytometry platform, the Oswaldo Cruz Institute (IOC-FIOCRUZ) and the INCA sequencing platform for technical support on genetic testing. 


\section{Author's Information}

List of e-mails:

Daniela P. Mendes-de-Almeida: daniela.almeida@ini.fiocruz.br

Francianne Gomes Andrade: fandrade@inca.gov.br

Filipe Vicente dos Santos-Bueno: filipe.biomedicina@hotmail.com

Dayvison F. Saraiva Freitas: dayvison.freitas@ini.fiocruz.br

Rosely M. Zancopé-Oliveira: rosely.zancope@ini.fiocruz.br

Maria S. Pombo-de-Oliveira:mpombo@inca.gov.br

\section{References}

1. Wu U-I, Holland SM. Host susceptibility to non-tuberculous mycobacterial infections. Lancet Infect Dis. 2015;15:968-80.

2. Henkle E, Hedberg K, Schafer S, Novosad S, Winthrop KL. Population-based Incidence of Pulmonary Nontuberculous Mycobacterial Disease in Oregon 2007 to 2012. Ann Am Thorac Soc. 2015;12:642-7.

3. Stout JE, Koh W-J, Yew WW. Update on pulmonary disease due to non-tuberculous mycobacteria. Int J Infect Dis. 2016;45:123-34.

4. Lee PP, Lau Y-L. 2017. Cellular and Molecular Defects Underlying Invasive Fungal Infections-Revelations from Endemic Mycoses. Front Immunol 8.

5. Hsu AP, Sampaio EP, Khan J, Calvo KR, Lemieux JE, Patel SY, Frucht DM, Vinh DC, Auth RD, Freeman AF, Olivier KN, Uzel G, Zerbe CS, Spalding C, Pittaluga S, Raffeld M, Kuhns DB, Ding L, Paulson ML, Marciano BE, Gea-Banacloche JC, Orange JS, Cuellar-Rodriguez J, Hickstein DD, Holland SM. Mutations in GATA2 are associated with the autosomal dominant and sporadic monocytopenia and mycobacterial infection (MonoMAC) syndrome. Blood. 2011;118:2653-5.

6. Luesink M, Hollink IHIM, van der Velden VHJ, Knops RHJN, Boezeman JBM, de Haas V, Trka J, Baruchel A, Reinhardt D, van der Reijden BA, van den Heuvel-Eibrink MM, Zwaan CM, Jansen JH. High GATA2 expression is a poor prognostic marker in pediatric acute myeloid leukemia. Blood. 2012;120:2064-75.

7. Wang X, Muramatsu H, Okuno Y, Sakaguchi H, Yoshida K, Kawashima N, Xu Y, Shiraishi Y, Chiba K, Tanaka H, Saito S, Nakazawa Y, Masunari T, Hirose T, Elmahdi S, Narita A, Doisaki S, Ismael O, Makishima H, Hama A, Miyano S, Takahashi Y, Ogawa S, Kojima S. GATA2 and secondary mutations in familial myelodysplastic syndromes and pediatric myeloid malignancies. Haematologica. 2015;100:e398-401.

8. Hahn CN, Chong C-E, Carmichael CL, Wilkins EJ, Brautigan PJ, Li X-C, Babic M, Lin M, Carmagnac A, Lee YK, Kok CH, Gagliardi L, Friend KL, Ekert PG, Butcher CM, Brown AL, Lewis ID, To LB, Timms AE, Storek J, Moore S, Altree M, Escher R, Bardy PG, Suthers GK, D'Andrea RJ, Horwitz MS, Scott HS. Heritable GATA2 mutations associated with familial myelodysplastic syndrome and acute myeloid leukemia. Nat Genet. 2011;43:1012-7.

9. Mendes-de-Almeida DP, Andrade FG, Borges G, dos Santos-Bueno FV, Vieira IF, da Rocha LKM da Mendes-da-Cruz S, ZancopéOliveira DA, Calado RM, Pombo-de-Oliveira RT MS. 2019. GATA2 mutation in long stand Mycobacterium kansasii infection, myelodysplasia and MonoMAC syndrome: a case-report. BMC Med Genet 20.

10. Donadieu J, Lamant M, Fieschi C, de Fontbrune FS, Caye A, Ouachee M, Beaupain B, Bustamante J, Poirel HA, Isidor B, Van Den Neste E, Neel A, Nimubona S, Toutain F, Barlogis V, Schleinitz N, Leblanc T, Rohrlich P, Suarez F, Ranta D, Chahla WA, Bruno B, Terriou L, Francois S, Lioure B, Ahle G, Bachelerie F, Preudhomme C, Delabesse E, Cave H, Bellanné-Chantelot C, Pasquet M. Natural history of GATA2 deficiency in a survey of 79 French and Belgian patients. Haematologica. 2018;103:1278-87.

11. Chong C-E, Venugopal P, Stokes PH, Lee YK, Brautigan PJ, Yeung DTO, Babic M, Engler GA, Lane SW, Klingler-Hoffmann M, Matthews JM, D’Andrea RJ, Brown AL, Hahn CN, Scott HS. Differential effects on gene transcription and hematopoietic differentiation correlate with GATA2 mutant disease phenotypes. Leukemia. 2018;32:194-202.

12. Liu X, Jiang B, Wang A, Di J, Wang Z, Chen L, Su X. GATA2 rs2335052 Polymorphism Predicts the Survival of Patients with Colorectal Cancer. PLOS ONE. 2015;10:e0136020. 
13. Rodriguez-Bravo V, Carceles-Cordon M, Hoshida Y, Cordon-Cardo C, Galsky MD, Domingo-Domenech J. The role of GATA2 in lethal prostate cancer aggressiveness. Nat Rev Urol. 2017;14:38-48.

14. Spinner MA, Sanchez LA, Hsu AP, Shaw PA, Zerbe CS, Calvo KR, Arthur DC, Gu W, Gould CM, Brewer CC, Cowen EW, Freeman AF, Olivier KN, Uzel G, Zelazny AM, Daub JR, Spalding CD, Claypool RJ, Giri NK, Alter BP, Mace EM, Orange JS, Cuellar-Rodriguez J, Hickstein DD, Holland SM. GATA2 deficiency: a protean disorder of hematopoiesis, lymphatics, and immunity. Blood.

2014;123:809-21.

\section{Figures}

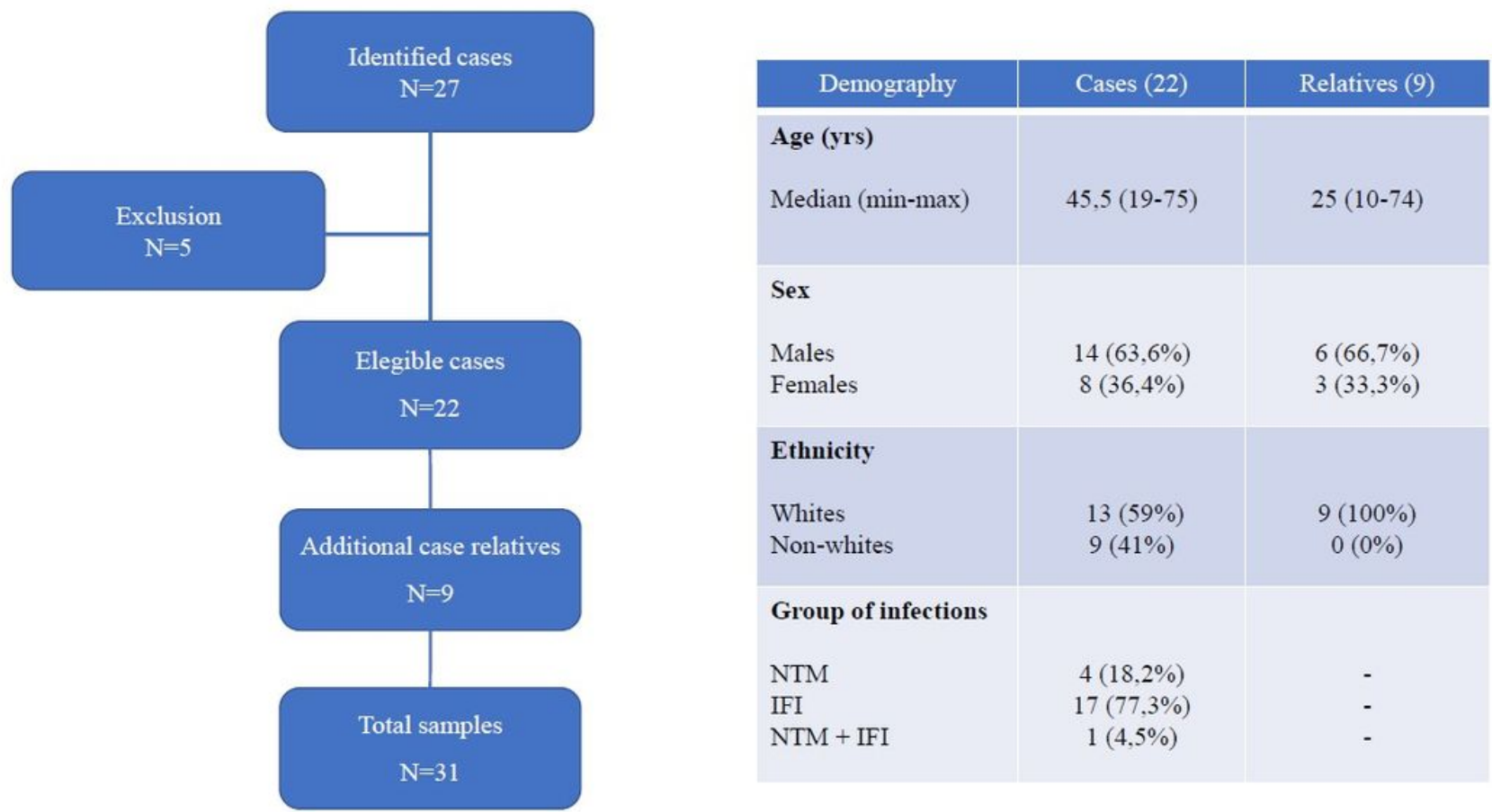

\section{Figure 1}

Study design of non-tuberculous mycobacteria or fungal infection patients with GATA2 haplodefficiency, Brazil, 2015-2018 Flowchart exhibiting 27 identified cases, 5 patients were excluded because they refuse to participate, remaining 22 elegible cases. After, 9 additional relatives from a single family were included, resulting in a total of 31 samples for genotyping. The age median for patients was 45,5 years (range from 19 to 75 ) and for relatives was 25 years (range from 10 to 74). Male sex and white ethnicity were more frequent among both patients and relatives. The most frequent group of infections observed was IFI (77,3\%). $\mathrm{n}$ - number of individuals; NTM- non-tuberculous mycobacteria; IFI- invasive fungal infection. 


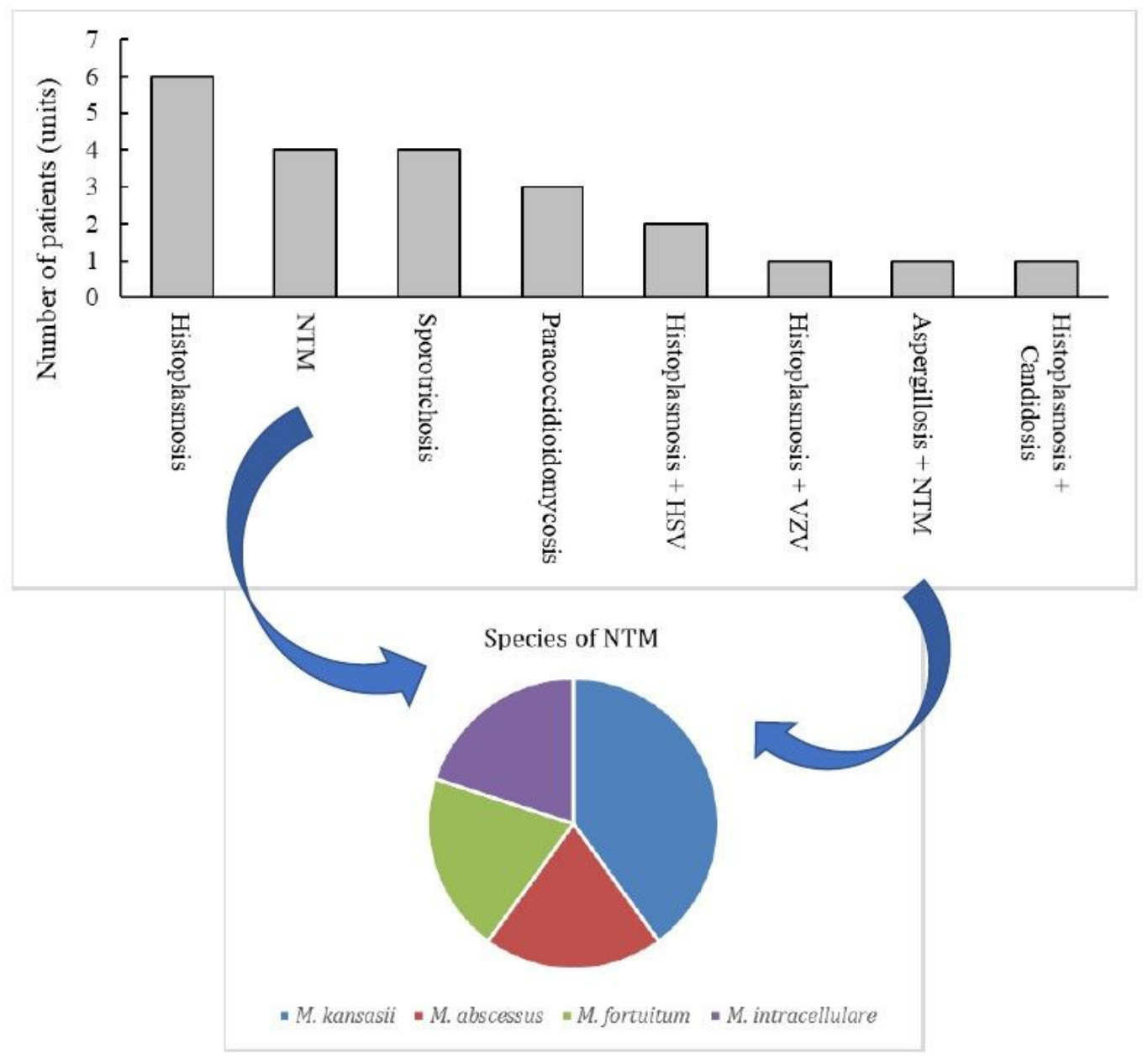

Figure 2

Frequency of mycobacterial and fungal infections in 22 ascertain patients Histoplasmosis was the most prevalent infection, identified isolated in 6 patients and in combination to other infections in 3 (total 9 patients). Among 5 NTM infections, the most prevalent specie was M. Kansasii (2), followed equaly by M. Abscessus, M. fortuitum and M. intracellulare. NTM- Nontuberculous mycobacteria; VZVVaricella zoster virus; HSV- Herpes simplex virus.

\section{Supplementary Files}

This is a list of supplementary files associated with this preprint. Click to download.

- Additionalfiles.docx 